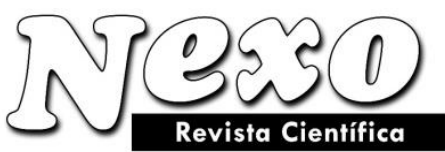

Vol. 34, No. 02, pp. 682-697/Junio 2021
ISSN-E 1995-9516

Universidad Nacional de Ingeniería COPYRIGHT @ (UNI). TODOS LOS DERECHOS RESERVADOS http://revistas.uni.edu.ni/index.php/Nexo https://doi.org/10.5377/nexo.v34i02.11552

\title{
Evaluation of WRF microphysics schemes in the simulation of a squall line over IRAN using radar and reanalysis data
}

\section{Evaluación de esquemas de microfísica WRF en la simulación de una línea de turbonada sobre IRAN utilizando datos de radar y de reanálisis}

\author{
Mahnaz Karimkhani ${ }^{1}$, Majid Azadi ${ }^{2 *}$, Amir Hussain Meshkatee ${ }^{1}$, Abbas Ranjbar Saadatabadi ${ }^{2}$ \\ ${ }^{1}$ Department of Earth Science, Science and Research Branch, Islamic Azad University, Tehran, \\ Iran. \\ ${ }^{2}$ Atmospheric Science and Meteorological Research Center, Tehran, Iran. \\ *azadi68@hotmail.com
}

(recibido/received: 29-diciembre-2020; aceptado/accepted: 22-febrero-2021)

\begin{abstract}
A squall line was recorded in Dayyer port over southwest of Iran, on 19 Mar 2017. In the present paper, we have simulated the characteristic features associated with the squall line by Weather Research and Forecasting (WRF) model using five different microphysics (MP) schemes. For validating the simulated characteristics of the squall line, the latitude-height and longitude-height cross section reflectivity and precipitation value derived from observed reflectivity gathered by Doppler Weather Radar at Bushehr, synoptic weather station data at Dayyer port along with NCEP-NCAR and ERA-INTERIM reanalyzes data were used. To verify the simulated precipitation, the Fractions Skill Score (FSS) curve was calculated. Examining the simulation results for geopotential and sea level pressure show that the model simulations using different MP schemes, agree well with the verifying reanalyzes. Also, the spatial rainfall distribution of simulations and verifying observations did not show big differences. However, there are significant differences in the details of simulations such as the maximum reflectivity of the convective cells, vertical extent of the storm cells, speed and direction of the wind, rainfall values and FSS curves. Though, all of the simulations have shown convective cells over Dayyer port at the time of occurrence of the squall line, but, only the model simulation using Lin MP scheme is consistent with the corresponding radar reflectivity and vertical extent. The FSS chart showed that the skill changes with spatial scale. Results using Lin microphysics scheme crossed the FSSuniform line at lower scales when compared to other MP schemes.
\end{abstract}

Keywords: Weather Research and Forecasting, Microphysics scheme, Doppler Weather Radar data, Fractions Skill Score.

\section{RESUMEN}

Se registró una línea de turbonada en el puerto de Dayyer, al suroeste de Irán, el 19 de marzo de 2017. En el presente documento, hemos simulado los rasgos característicos asociados con la línea de turbonada mediante el modelo de investigación y pronóstico meteorológico (WRF) utilizando cinco microfísicas diferentes (MP) esquemas. Para validar las características simuladas de la línea de turbonada, la 
reflectividad de la sección transversal de latitud-altura y longitud-altura y el valor de precipitación derivado de la reflectividad observada recopilada por el radar meteorológico Doppler en Bushehr, datos de la estación meteorológica sinóptica en el puerto de Dayyer junto con NCEP-NCAR y ERA -Se utilizaron datos de reanálisisINTERIM. Para verificar la precipitación simulada, se calculó la curva Fractions Skill Score (FSS). El examen de los resultados de la simulación de la presión geopotencial y al nivel del mar muestra que las simulaciones del modelo que utilizan diferentes esquemas de MP concuerdan bien con los reanálisis de verificación. Además, la distribución espacial de las precipitaciones de las simulaciones y las observaciones de verificación no mostraron grandes diferencias. Sin embargo, existen diferencias significativas en los detalles de las simulaciones, como la reflectividad máxima de las celdas convectivas, la extensión vertical de las celdas de tormenta, la velocidad y dirección del viento, los valores de precipitación y las curvas FSS. Sin embargo, todas las simulaciones han mostrado celdas convectivas sobre el puerto de Dayyer en el momento de la aparición de la línea de turbonada, pero solo la simulación del modelo que usa el esquema Lin MP es consistente con la reflectividad del radar y la extensión vertical correspondientes. El gráfico FSS mostró que la habilidad cambia con la escala espacial. Los resultados utilizando el esquema de microfísica Lin cruzaron la línea FSSuniform a escalas más bajas en comparación con otros esquemas de MP.

Palabras clave: Investigación y pronóstico del tiempo, esquema de microfísica, datos del radar meteorológico Doppler, puntaje de habilidad de fracciones.

\section{INTRODUCCIÓN}

Mesoscale convective systems that are linear or quasi-linear can generate heavy rains, hail, detrimental winds, and even sometimes tornadoes, called squall line (Meng et al. 2012). Radar images can show development, movement (Wong and Yip 2006) and arc shape (Meng et al. 2011) of squall lines. The bowing of squall lines is commonly associated with swaths of detrimental winds (Fujita 1978). Prediction of thunderstorms and squall lines are especially important to space vehicle launch operations, aviation, electricity services, to name a few. The methods for predicting thunderstorms can be arranged into two categories (Wilson et al. 1998). One method is a historical treatment of thunderstorm extrapolation techniques, first assuming no change in motion, size and intensity and second allowing for changes in size and intensity based on past trends (Wilson et al., 1998).

The second technique is consisted of using the numerical weather prediction (NWP) models. Prediction of squall line and thunderstorm is one of the hardest jobs in weather prediction, owing to small spatial and temporal scales and the non-linearity of their physics and dynamics. The insufficient treatment of sub-grid convection is broadly believed to be a main barrier for improving the poor efficiency of NWP models in precipitation forecasting (Liu and Moncrieff 2007). Commonly, for evaluation the performance of NWP models, the simulated thermodynamic or/and kinematic fields are compared against the corresponding observations (Jankov et al. 2010). For example, the parameters for comparison may include pressure, temperature, surface winds and precipitation values. Simulations of precipitation with high resolution 3-6 $\mathrm{km}$ grid spacing using convection configuration showed good agreement (Done et al. 2004; Trier et al. 2006; Liu et al. 2006; Moncrieff and Liu 2006; Lean et al. 2008; Kain et al. 2008). There are various causes for better performance with the high resolution models. Also, many studies have shown that decreasing the horizontal grid spacing of the model may raise the model's capability to simulate thunderstorm and precipitation (McQueen et al. 1995; Katzfey 1995; Martin 1996; Doyle 1997; Colle et al. 1999; Davis and Carr 2000; Adlerman and Droegemeier 2002; Petch et al. 2002; Bryan et al. 2003; Kain at el. 2006, 2008; Xue and Martin 2006; Schwartz at el. 2009; Weisman et al. 2008). Done et al. (2004) run the model with two configurations, one of them with 10-km and the other one with 4-km grid spacing. Their research showed that forecasts with 4-km resolution showed better results when compared with those with 10-km. Kain et al. (2008) run WRF model to generate 5 and 7 day forecasts with the same 
boundary and initial conditions, same physical configurations, but different horizontal resolutions. The results showed that horizontal resolution of $2 \mathrm{~km}$ captures more details. Therefore, we used model output with $3 \mathrm{~km}$ grid spacing for Check the results.

Cloud microphysical operations play a significant role via influences on the latent heating (owing to condensation) and cold pool stability (owing to rainfall evaporation) (Rajeevan et al. 2010). Hence, microphysical parameterizations could be a main basis of uncertainty in convection in the predictions of NWP model simulations. Therefore, an important concern in convection models is microphysics parameterization (MP). Various researches have been conducted to reveal the cloud microphysics sensitivity of the models with in the prediction of thunderstorms, squall lines and associated precipitations over different region (e.g. McCumber 1991; Reisner et al. 1998; Gilmore et al. 2004; Naegele 2014; Tan 2016; Shrestha et al. 2017; Stergiou et al. 2017; Chawla et al. 2018; Eltahan and Magooda 2018; Gboode et al. 2018). Rajeevan et al. (2010) examined sensitivity of the WRF cloud microphysics to simulations of a severe thunderstorm event over southeast India. They simulated the thunderstorm using four different MP schemes. However, all the schemes underestimated stability and vertical extent of the updraft cores. Also, the microphysics schemes displayed problems in the downdrafts. While the Thompson scheme simulated rainfall closer to the actual rainfall, the other three MP schemes overestimated rainfall. Tao et al. (2011) investigated the impact of microphysics schemes on Katrina hurricane. In general, they found that microphysics schemes do not have an impact on simulated storm track but do have a major effect on the simulated intensity. Song and Sohn (2018) evaluated the WRF microphysical schemes for the simulation of heavy rain over the Korean peninsula, and found that the WRF Double Moment 6-class (WDM6) scheme was the best scheme for simulation of heavy rainfall. Our work is similar to the works conducted in the above mentioned references with some differences in the methods used for verification of the results including the results of simulation of vertical profile of maximum reflectivity, simulation of 24$\mathrm{h}$ precipitation accumulation, simulation of wind speed and direction and Fractions skill score.

New methods for verifying precipitation have been presented in recent years. These methods provide fractions skill score. Procedures have been explained by Ebert and McBride (2000), Casati et al. (2004), Davis et al. (2006). Robert and Lean (2008) have used radar data for precipitation accumulations for convective event to find the forecast skill.

In this research, we have simulated a squall line and seiche event that occurred over Dayyer port and Jam stations located in southwest of Iran on 19 Mar 2017 and searched the sensitivity of the WRF simulations to various cloud microphysics schemes: Lin, WSM6, Morrison, Thompson and Thompson aerosol-aware. In general, our work is very much similar to Tan, (2016); Shrestha et al. (2017) and Chawla et al. (2018), but the main purpose of the current paper is to investigate the ability of the current operational modeling system used in I.R. of Iran Meteorological Organization (IRIMO) for the prediction of squall lines which frequently occur over the southern Iran. It is to be mentioned that prediction of squall line and associated weather is a challenging task and sometimes are missed in the prediction. For example, the selected case in this study was not well predicted by the forecasting center at the time. Therefore, we want to research predictability of the squall lines and the model sensitivity to various microphysics.

In Section 2, data and methodology are described. The Section 3 the main results of the simulations are presented and the conclusions are drawn in Section 4.

\section{DATA AND METHODOLOGY}

In this study, we use the Advanced Research version of WRF (ARW), version 3.9, which is a compressible, nonhydrostatic and scalar-conserving state-of-the-art atmospheric model (Skamarock et al. 2005) for the simulations of the Squall line and seiche events associated with the thunderstorm observed over Dayyer port located in southwest of IRAN on 19 Mar 2017. For model simulations, we have considered a configuration with three nested domains of $27 \mathrm{~km}, 9 \mathrm{~km}$ and $3 \mathrm{~km}$ grid spacing. The domain 
configurations used for model simulations is shown in Figure 1. All runs were initialized at 18:00 UTC 18 Mar 2017 and Global Forecast System (GFS) data with 0.5degree horizontal resolution were used for initial and boundary conditions.

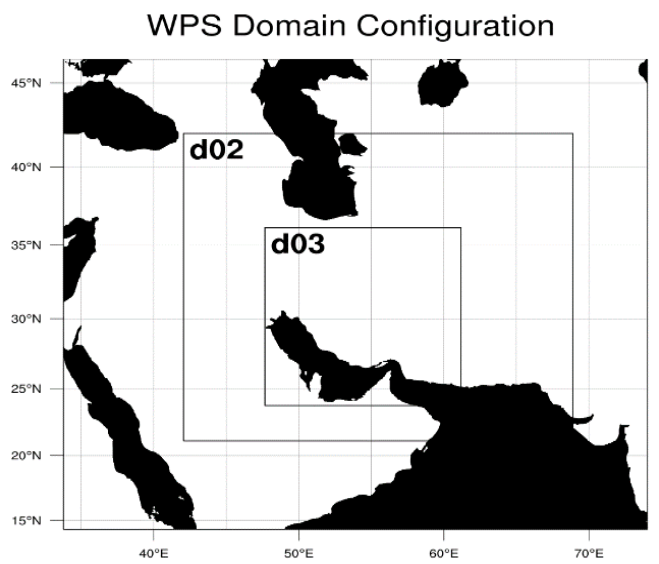

Figure 1. model domains used for the simulation of the squall line. Domain resolution is $27 \mathrm{~km}, 9 \mathrm{~km}$ and $3 \mathrm{~km}$, respectively

To evaluate the sensitivity of the model simulations (forecast) to cloud microphysics, five microphysical schemes were tested. Microphysics in the WRF model includes cloud, water vapor and precipitation processes. The schemes considered are Lin (Chen and Sun 2002), WSM6 (Hong et al. 2004), Thompson (Thompson et al. 2004), Morrison (Morrison et al. 2009) and Thompson aerosol aware (Thompson and Eidhammer 2014) schemes. All five schemes used, divide condensed water into cloud liquid, snow, cloud ice, rain, and graupel.

The Lin scheme is according to Lin et al. (1983), Rutledge and Hobbs (1984) and Chen and Sun (2002), modification is based on Tao et al. (1989) for ice sedimentation and saturation adjustment. The WSM6 scheme is based on Tao et al. (1989), with a different accretion calculation (Hong and Lim 2006). Split time is applied to the melting and freezing processes for increasing accuracy in the vertical heating profile. The saturation adjustment follows Dudhia (1989) and Hong et al. (1998) in separately processing ice and water saturation. In the Thompson scheme (Thompson et al. 2004) a variable has been added to predict the concentration of cloud ice. In this scheme ice nucleation and autoconversion is calculated according to Cooper (1986) and Walko et al. (1995) respectively. For graupel category represents a gamma function. All hydrometeors in the Morrison's double-moment scheme (Morrison and Pinto 2005, 2006) except for cloud water are double moment.

One of the factors affecting cloud microphysics is Aerosol chemistry (rajeevan et al. 2010). Khain et al. (2005) investigated the effect of aerosols on dynamics and cloud microphysics and found a significant effect. Clouds arising under aerosol conditions produce a powerful downdrafts and strong convergence in the boundary layer. As such, aerosols can contribute to the formation of convective cells and thunderstorms. Being triggered by dynamical forcing, clouds arising in microphysically air are stronger and can produce a squall line. Because of this, we will also review a version of Thompson aerosol aware scheme (Thompson and Eidhammer 2014), that was carried out into the WRF model from 2014, and considers water- and ice-friendly aerosols.

The Yonsei University (YSU) PBL scheme (Troen and Mahrt 1986) was used to parametrize the PBL processes. For longwave and shortwave radiation, the Rapid Radiative Transfer Model (Mlawer et al. 1997) and Dudhia scheme (Dudhia 1989), were used respectively. All simulations in the ARW-WRF model were performed with 30 vertical levels. For all simulations and in the first and second domains the 
Betts Miller Janjic (BMJ) Cumulus parameterization scheme (Janjic 1994) was used while the convection for inner domain (3 km grid spacing) was considered zero. The first 12 hour of the simulation was considered as the spin-up time. Therefore, for discussions, we have used only the results from 00:00UTC of 19 Mar 2017 onward. All runs were initialized at 1200 UTC 18 Mar 2018 and Global Forecast System (GFS) data with 0.5degree horizontal resolution (forecast NCEP GFS data) was used for initial and boundary conditions.

The main objectives of this paper are to investigate if the WRF model with high resolution is capable of capturing the observed characteristics of the squall line, to evaluate the reactivity of simulation to varying microphysics and also to investigate predictability of the squall line by the WRF model. To this end, the vertical profile of maximum reflectivity associated with the squall line, spatial distribution of 24-h precipitation accumulation and surface wind (speed and direction), were examined first. Then the fractions skill score for precipitation verification was applied. To perform the fractions skill score method, the base reflectivity data for elevation angle $0.5^{\circ}$ (Brandes et al. 1999) from Bushehr Doppler Weather Radar over southwest Iran and the Marshal-Palmer equation for calculating precipitation are used to estimate the forecast and radar data in a same grid. Four thresholds of $0.5,5,10$ and $15 \mathrm{~mm}$ and $95^{\text {th }}$ percentile threshold (as threshold to represent the heaviest precipitation in the system) are considered and used to convert the forecast and radar precipitation into binary ( $\mathrm{I}_{\mathrm{O}}$ and $\mathrm{I}_{\mathrm{M}}$ ) and the fractions skill score (FSS) were calculated, according to:

$$
F S S_{(n)}=\frac{M S E_{(n)}-M S E_{(n) r e f}}{M S E_{(n) p e r f e c t}-M S E_{(n) r e f}}=1-\frac{M S E_{(n)}}{M S E_{(n) r e f}}
$$

Where, the reference MSE (MSE(n)ref) and $\operatorname{MSE}_{(\mathrm{n})}$ are given by,

$$
\begin{aligned}
& \operatorname{MSE}_{(n) r e f}=\frac{2}{N_{x} N_{y}}\left[\sum_{i=1}^{N_{x}} \sum_{j=1}^{N_{y}} O_{(n) i, j}^{2}+\sum_{i=1}^{N_{x}} \sum_{j=1}^{N_{y}} M_{(n) i, j}^{2}\right] \\
& \operatorname{MSE}_{(n)}=\frac{1}{N_{x} N_{y}} \sum_{i=1}^{N_{x}} \sum_{j=1}^{N_{y}}\left[O_{(n) i, j}-M_{(n) i, j}\right]^{2}
\end{aligned}
$$

Where $N_{x}$ and $N_{y}$ are the number of columns and rows in the domain, $O(n) i, j$ and $M(n) i, j$ are observed and forecast fractions obtained from IO and IM. Then, the FSS curve is plotted for neighborhood length (n) (Refer to Robert and Lean 2008).

Also, for verifying simulated characteristics of the squall line, the synoptic data at Dayyer port and JAM stations and Doppler Weather Radar (DWR) data were used.

\section{RESULTS AND DISCUSSIONS}

\subsection{Details of the squall line}

The squall line convective phenomenon and the seiche event occurred in the morning of 19 March 2017 over southwest of Iran and were recorded in Dayyer port and Jam synoptic meteorological stations. shows the spatial and time distribution of maximum reflectivity observed by the DWR at Bushehr station which represents the genesis, growth and extension of the squall line event. The start of the event was observed over west side of the Persian Gulf around 0000 UTC 19 March 2017, then the convective cells grew and moved east (Figure 2a, b). At 0300 UTC (Figure 2c), in the center of the Persian Gulf, they formed a squall line. This squall line could be seen around Dayyer station at 0330 UTC (Figure 2d) and 0400 UTC (Figure 2e) and also, could be seen around Jam station at 0430 UTC (Figure 2f). The squall line started dissipating around 0500 UTC. Due to the passage of the squall line, strong wind and cold air subsidence 
took place over the Persian Gulf that generated a standing wave and seiche event over the Dayyer port and Jam.
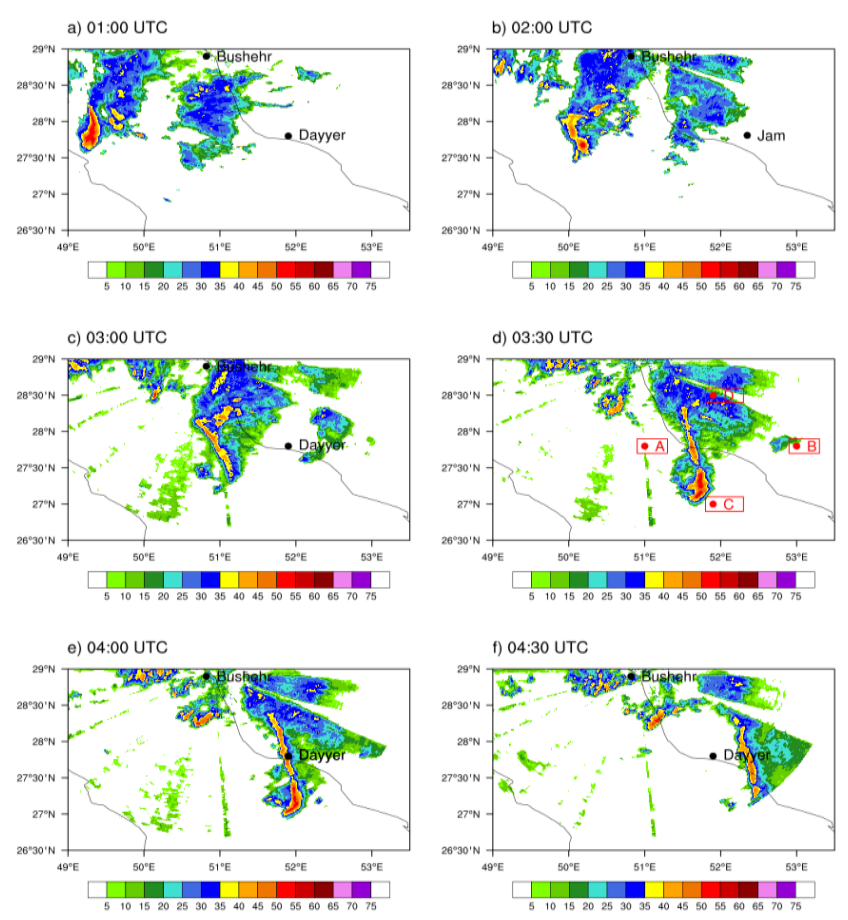

Figure 2. Time series of maximum reflectivity observed by the Bushehr Radar at (a) 0100 UTC, (b) 0200 UTC, (c) 0300UTC, (d) 0330 UTC, (e) 0400 UTC and (f) 0430 UTC 19 March 2017. Point A to B is longitude-height interval for cross section in figure $5 \mathrm{a}$. Point $\mathrm{C}$ to $\mathrm{D}$ is latitude-height interval for cross section in figure $5 \mathrm{~b}$.

Time series of mean sea level pressure, 2-m temperature and 10-m wind speed over Jam station on 19 March 2017 are given in Figure 3, before and after the passage of the squall line. Surface pressure fluctuations noted in the both stations show that the convective cells are located over the stations. The temperature shows cooling associated with the passage of squall line. The cooling was about $4{ }^{\circ} \mathrm{C}$ in just four hours. Also, the wind speed increased up to 8 in Jam station. This variation of the wind speed, temperature and surface pressure, clearly show the passage of the squall line.

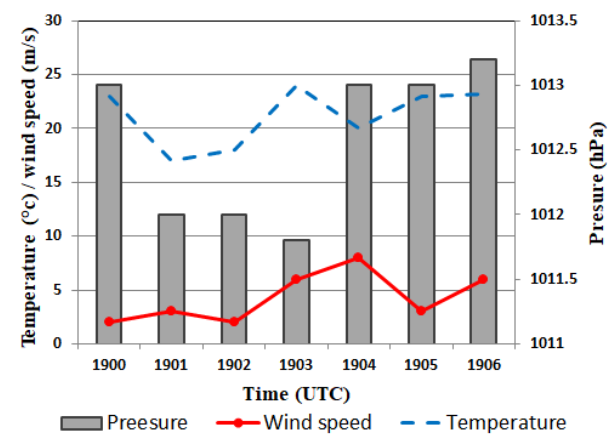

Figure 3. Pressure (vertical bar), temperature (continuous line) and wind speed observed over Jam station on 19 March 2017

Figure 4 shows contour map of 24-hour accumulated rainfall $(\mathrm{mm})$ from 06UTC 18 to 06UTC 19 Mar 2017 observed in the east of the Persian Gulf plotted using rain-gauge observations (from I.R. Iran Meteorological Organization). The maximum of 24-h precipitation accumulation is $78.3 \mathrm{~mm}$ between $27.5^{\circ} \mathrm{N}-28^{\circ} \mathrm{N}$ and $51.9^{\circ} \mathrm{E}$ (Jam and Dayyer location and the squall line passageway). 


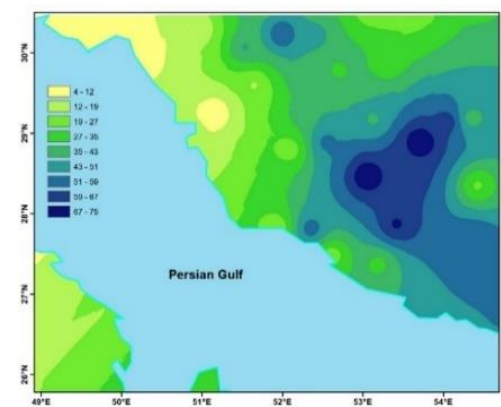

Figure 4. 24h accumulated rainfall $(\mathrm{mm})$ from 06UTC 18 to 06UTC 19 Mar 2017 from rain-gauge and synoptic observation
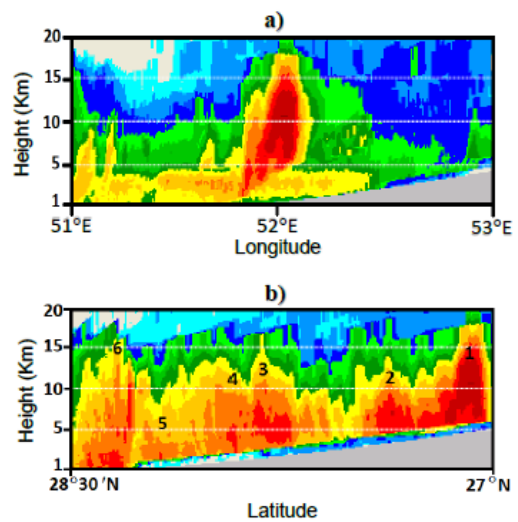

Figure 5a. shows longitude-height cross section $\left(27.8^{\circ} \mathrm{N}\right)$ of reflectivity over $50-53^{\circ} \mathrm{E}$ at $04: 00 \mathrm{UTC} 19$ Mar 2017 (At the same time as passing the squall line) recorded by Bushehr radar. It shown a sharp vertical extent in reflectivity around 16661 meters as the squall line passed over $52^{\circ} \mathrm{E}$. This cell has a maximum reflectivity around $60.28 \mathrm{dBZ}$. Also, The observed latitude-height cross section (51.9) of reflectivity over $27-28.5^{\circ} \mathrm{N}$ at 04:00UTC 19 Mar 2017 measured by the Doppler weather radar at Bushehr

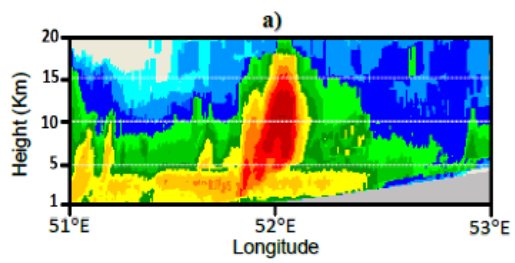

is shown in

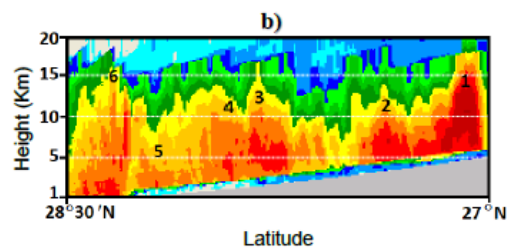


Figure $5 \mathrm{~b}$. This squall line consists of six convective cells that shown in
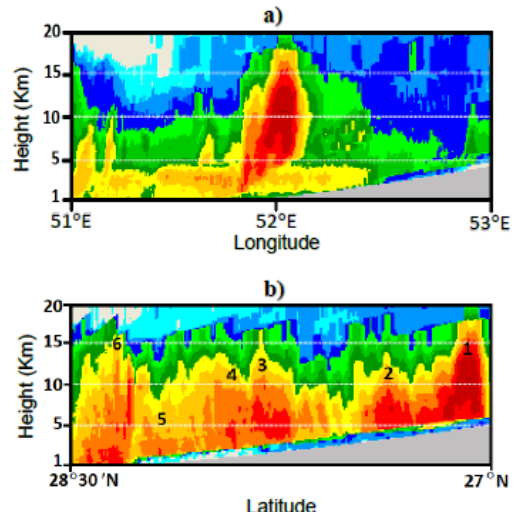

Figure $5 \mathrm{~b}$. The first cell has strong rise in reflectivity around $15 \mathrm{~km}$ as the squall line passed over Dayyer port. Three, four and six cells have vertical extent around $10 \mathrm{~km}$ with maximum reflectivity about 55dBZ. The second core over Dayyer port was observed extending up to $5 \mathrm{~km}$, and the fifth cell has grown a little and is about $5 \mathrm{~km}$.
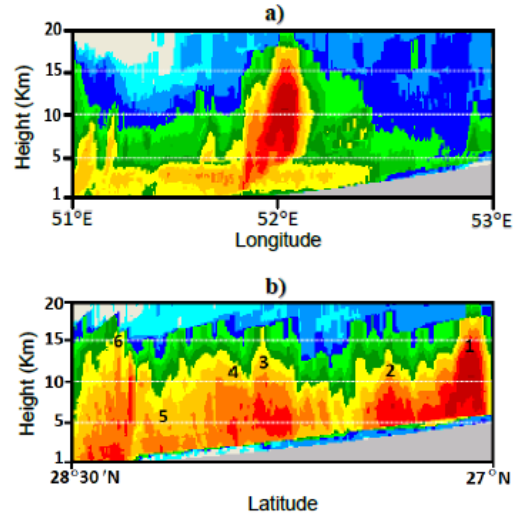

Figure 5. (a) longitude-height Cross section and (b) latitude-height cross section of reflectivity at Dayyer port on 04:00UTC 19 Mar 2017 recorded by Bushehr radar

Figure 6 portrays 6-h (00:00 to 06:00UTC) mean and 30-year anomalies fields for 19 Mar 2017. The 925hPa geopotential height (Figure 6a) shows a cyclonic system with closed contour of $705 \mathrm{~m}$ over Iraq and Arabian Peninsula (west of Iran). The south and southeasterly flow associated with the low pressure is located over southwest of Iran along the coasts of the Persian Gulf (near the location of the squall line formation) bringing moisture from over the Persian Gulf to the coastal area. The 30-year anomalies of 925-hPa geopotential height (Figure 6b) show a negative anomaly with a value exceeding 60-m over Iraq and Arabian Peninsula (west of Iran). 500-hPa geopotential height contour map (Figure 6c) clearly shows a strong trough with the axis located over the west of Iran. The corresponding 30-year anomalies are shown in Figure 6d with the strong negative anomaly located in the region of the trough. The contour map of precipitatble water (Figure 6e) shows a region of deep humidity with a value more than 50 $\left(\mathrm{kgm}^{-2}\right)$ over southwest of Iran. The contour map of the precipitable water anomaly shows at the maximum positive anomaly of $15\left(\mathrm{kgm}^{-2}\right)$ which is again located in the region of low pressure area (Figure 6f). Results of our past experience in this region (Arkian and Karimkhani; 2014) show that the value of $9 \mathrm{kgm}^{-2}$ for precipitate water is a critical value, above which the probability of precipitation is high. 


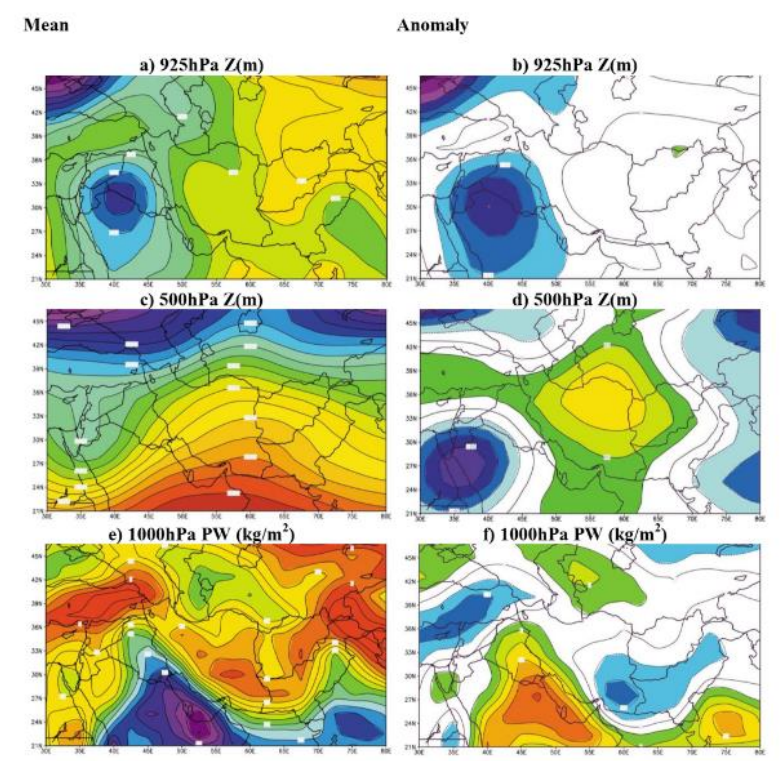

Figure 6. (a), (c) and (e) 6-h mean and (b), (d) and (f) anomaly field derived from NCEP-NCAR reanalysis data for 19 Mar 2017. The images are as follows: (a),(b) $925 \mathrm{hPa}$ geopotential height (m), (c),(d) $925 \mathrm{hPa}$ geopotential height (m) and (e),(f) $1000 \mathrm{hPa}$ precipitable water $\left(\mathrm{kgm}^{-2}\right)$. The squares show second and third WRF domains

\subsection{Comparison of simulated geo potential fields with reanalysis data}

To verify the model results, the simulated fields including $500-\mathrm{hPa}$ geopotential and mean sea level pressure are compared against the verifying ERA-INTERIM reanalysis dataset (Jankov et al. 2010). The simulated results for the outer domain ( $27 \mathrm{~km}$ resolution) along with the verifying reanalysis contour map for $500 \mathrm{hPa}$ geopotential heights are presented in Figure 7. The show results in Figure $7 \mathrm{~b}$ are for model run with the Lin scheme as microphysics. It is to be noted that the main features of the synoptic patterns shown in 500-hPa and sea level pressure maps are almost the same for all five aforementioned microphysics schemes used. As seen in Figure $7 \mathrm{~b}$ the simulated 500-hPa geopotential shows a through with axis in the southeast direction over southwest of Iran and agree well with the verifying reanalysis (Figure 7a). The same results hold for sea level pressure (Fig is not presented).
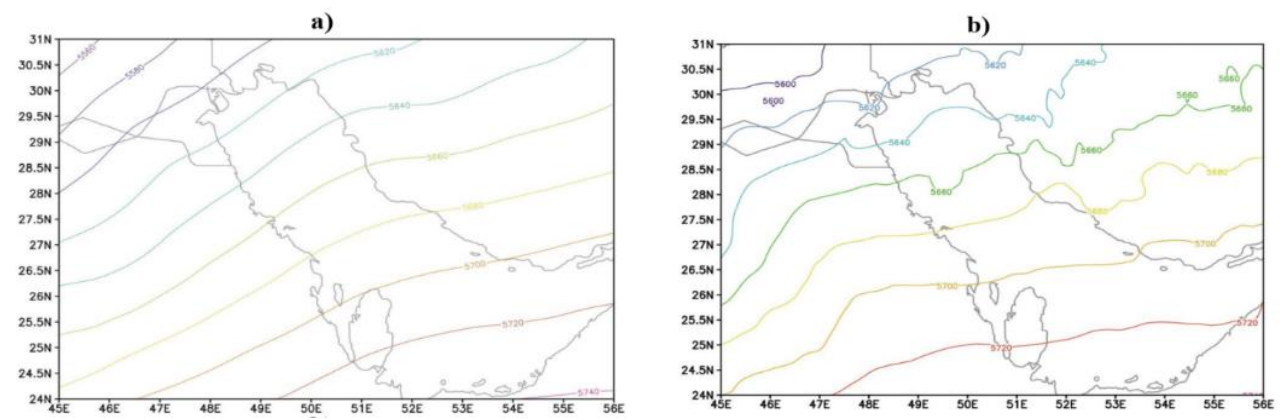

Figure 7. 6-h average (00:00UTC to 06:00UTC 19 Mar 2017) 500hPa geopotential height (m): (a) ERA-INTERIM reanalysis data and (b) simulation with Lin MP scheme

\subsection{Simulation of vertical profile of maximum reflectivity}

Figure 8 shows the latitude-height cross section $\left(51.9^{\circ} \mathrm{E}\right)$ of reflectivity over $27-28.5^{\circ} \mathrm{N}$ simulated by WRF model using five MP schemes at 04:00UTC 19 Mar 2017. The results for all simulations show multicell convective systems. But they are different in reflectivity and vertical extent. Looking at Figure 8, it is evident that the convective cores of the squall line have the highest reflectivity values for the Lin scheme 
and lower values for the Morrison scheme. It is seen that the highest reflectivity occurs at the altitude of $13000 \mathrm{~m}$. This indicates that there are stronger updrafts for the Lin scheme at 04:00, which is consistent
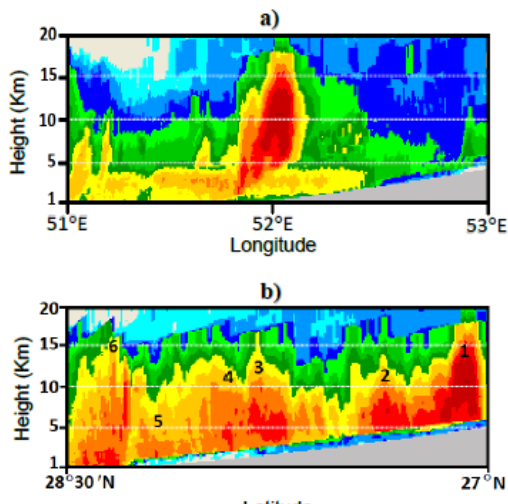

with the corresponding radar reflectivity (

Latitude

Figure $5 b$ ). Also the pattern of the multicell convective systems simulated by the model using Lin MP
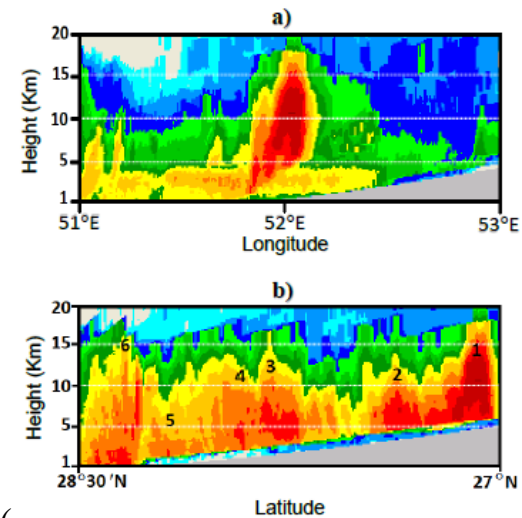

scheme is closer to the radar reflectivity (

Latitude Figure 5b).
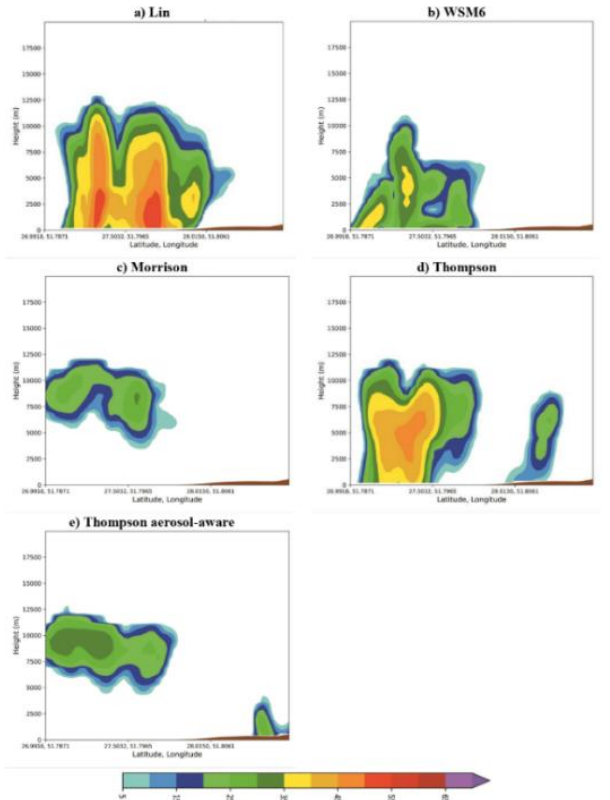

Figure 8. latitude-height cross section of reflectivity (dBZ) simulated by the model using five schemes (a) Lin, (b) WSM6, (c) Thompson, (d) Morrison, (f) Thompson aerosol-aware at 04:00UTC 19 Mar 2018 


\subsection{Simulation of 24-h precipitation accumulation}

24-h precipitation accumulations (mm) at 06UTC 18 to 19 Mar 2017 simulated by the model over the inner nest with five difference MP physics are presented in Figure 9 For five simulations with different MP schemes, the simulated spatial distribution of the precipitation amounts over southwest of IRAN was consistent with the corresponding observed precipitation accumulations (Figure 4). Though, the spatial distribution and areal coverage for five simulated patterns are similar but they differ from each other in terms of value. As such, the highest and lowest values of precipitation were simulated using Lin and Thompson schemes respectively.

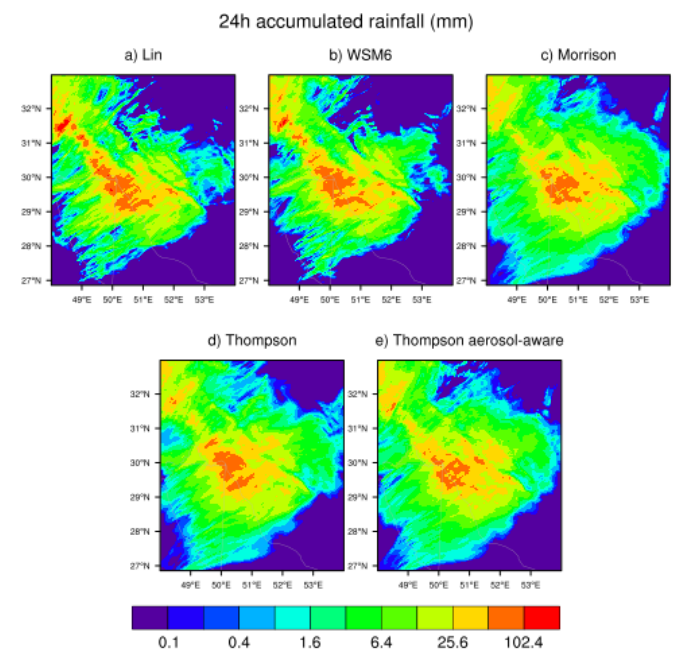

Figure 9. The 24-h precipitation accumulation (mm) at 06UTC 18 to 19 Mar 2017 over the inner nest simulated by the model with five MP schemes (a) Lin, (b) WSM6, (c) Morrison, (d) Thompson and (e) Thompson aerosol-aware Figure 10 shows 24 -h the observed maximum precipitation accumulation at 60 rain gauge and synoptic stations and corresponding values simulated by the model with five different MP schemes. Minimum and maximum error in maximum precipitation was seen at model forecast with Lin and WSM6 MP schemes, respectively. Forecasts using the Lin scheme show 58\%, 33\%, 56\% and 28\%, improvements when compared to those of WSM6, Morrison, Thompson and Thompson aerosol-aware MP schemes. These results were similar for minimum and total precipitation.

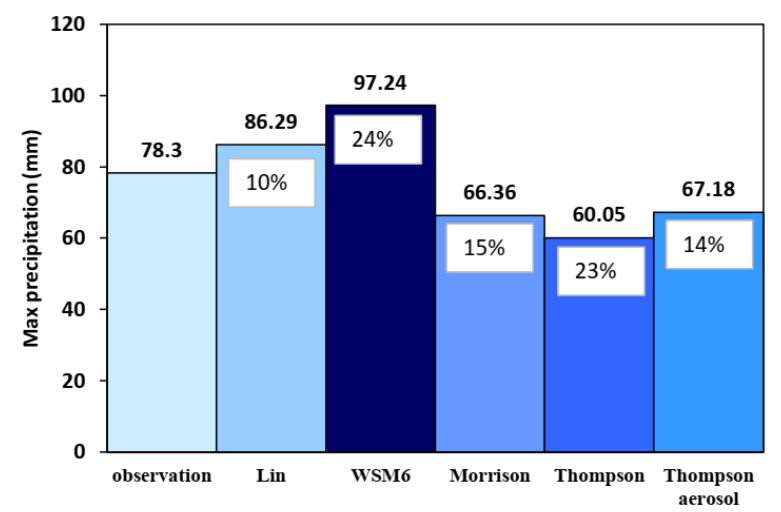

Figure 10. 24h maximum precipitation accumulation from 00:00UTC 19 to 20 Mar 2019 from rain gauge and model forecast with five MP schemes (box shows error)

\subsection{Fractions skill score of precipitation accumulations}

Due to the complexity of rainfall patterns, their prediction is difficult, but when the visual assessment of the precipitation forecast is similar to the observation, FSS is also consistent with this result (Robert and Lean 2008). To evaluate the simulation results quantitatively, the FSS method of Robert and Lean were used. Figure 11 shows the observed and simulated 12-h accumulated rainfall from 0000 to 1200 UTC 19 
Mar 2017. Fractions skill score charts are shown in Figure 12 for all the five forecasts using different MP schemes. To check the spatial accuracy of the forecasts, the 95th percentile threshold (about $14 \mathrm{~mm}$ as threshold to represent the heaviest precipitation in the system) was selected. The precipitation forecast for Morrison and Thompson aerosol-aware MP schemes showed relatively poor results in terms of precipitation area (Figure 11d, e). Figure 12 supports this view by showing that the forecasts using Morrison and Thompson aerosol-aware MP schemes are less skillful compared to a random forecast up to 450 and $250 \mathrm{~km}$ scales respectively.

The WRF model with Lin MP scheme predicted the spatial rainfall distribution well (Figure 12b), while the maximum rainfall value using WSM6 MP Scheme match well with the verifying observation (Figure 12c). FSS diagram also shows that for the Lin and WSM6 MP Schemes, the results for scales between 160 $\mathrm{km}$ and $\sim 120 \mathrm{~km}$ were better compared to the random forecasts. For the Lin, WSM6 and Thompson MP schemes, FSS exceeded FSS $_{\text {uniform }}$ at a scale of $\sim 340 \mathrm{~km}, \sim 360 \mathrm{~km}$ and $\sim 490 \mathrm{~km}$, respectively. For Morrison and Thompson aerosol-aware MP schemes, forecasts at all scales are less than FSS uniform. The use of a $95^{\text {th }}$ percentile threshold would lead to a very low FSS for Morrison and Thompson aerosol-aware MP schemes for all scales. So, the FSS will show good when the WRF model predicts both the spatial distribution and maximum rainfall well.

a) Radar

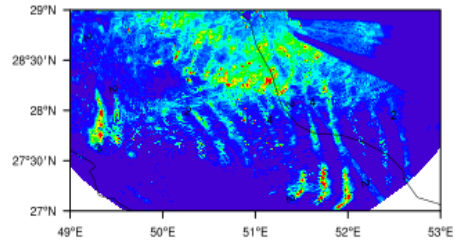

d) Morrison

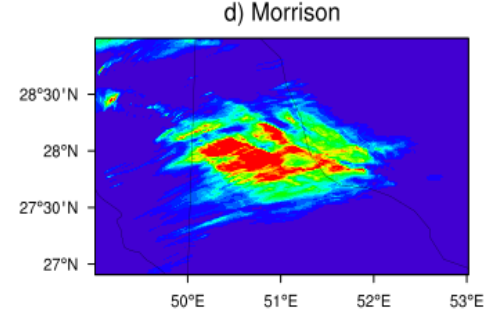

b) Lin

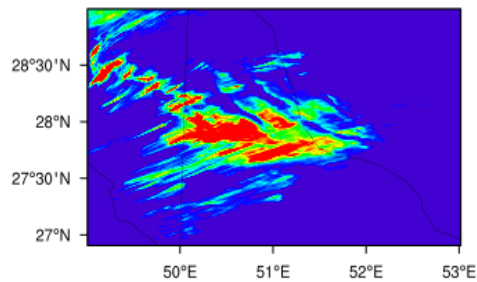

e) Thompson

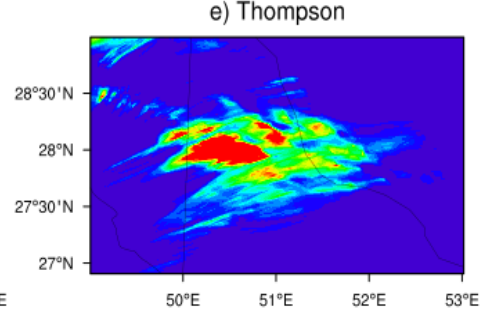

c) WSM6
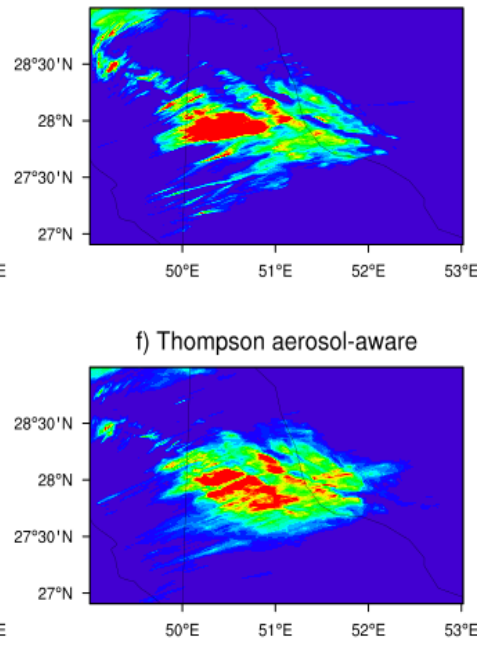

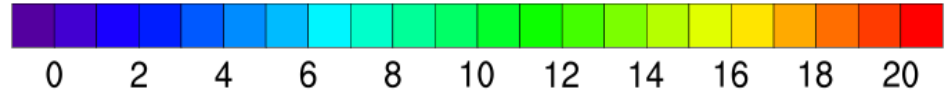

Figure 11. 12h accumulated rainfall over the period 0000-1200 UTC 19 Mar 2017 from (a) radar, the 3-km model forecast from (b) Lin, (c) WSM6, (d) Morrison, (e) Thompson and (f) Thompson aerosol-aware MP schemes

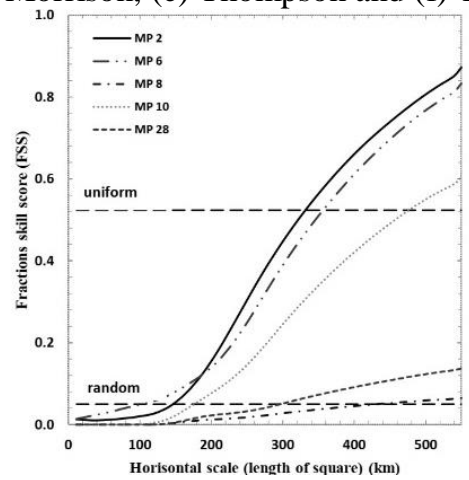

Figure 12. chart of FSS for 3-km model forecasts using a 95th percentile threshold for different MP schemes 
Chart of FSS for accumulation rainfall thresholds of 0.5, 5, 10 and $15 \mathrm{~mm}$ are displayed in Figure 13. For the smallest threshold $(0.5 \mathrm{~mm})$ the FSS values, using five different microphysics schemes, are greater

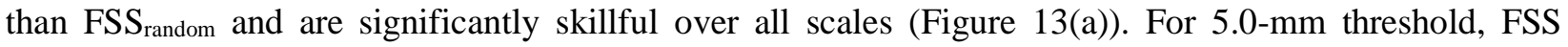

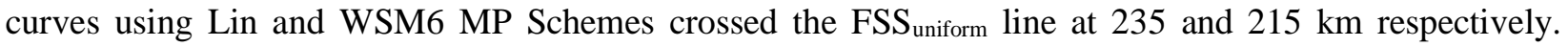

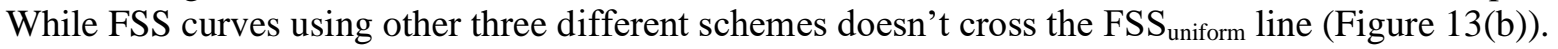

Generally, the FSS curves using Morrison and Thompson aerosol-aware microphysics schemes don't cross the FSS $_{\text {uniform }}$ except for the lowest threshold of $0.5 \mathrm{~mm}$ and thus show weaker performance compared to other schemes. For $10 \mathrm{~mm}$ threshold (Figure 13c), the FSS curves using Lin, WSM6 and Thompson MP schemes, cross the FSS $_{\text {uniform }}$ at 165, 175 and $205 \mathrm{~km}$ respectively. Two forecasts using Lin and WSM6 MP Schemes have the same FSS values for $15 \mathrm{~mm}$ threshold (Figure 13d).
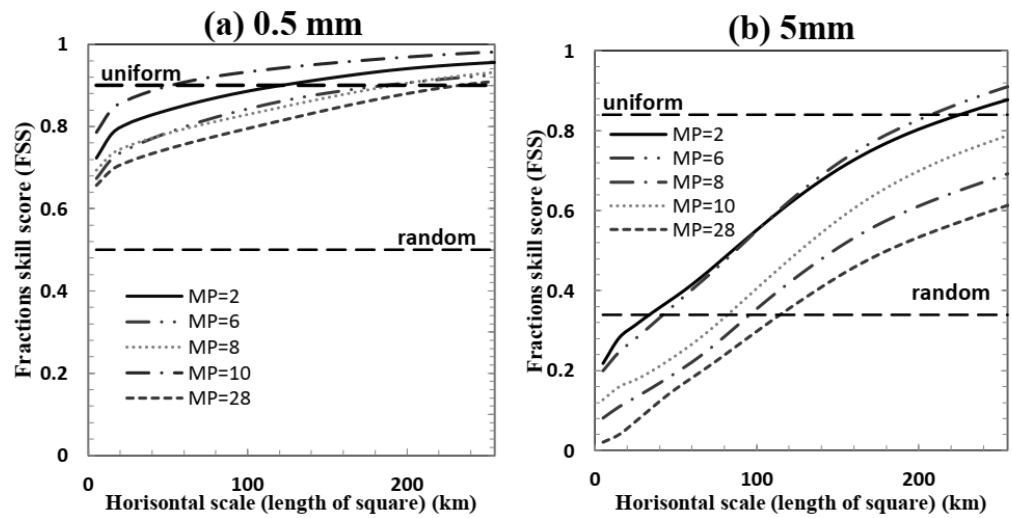

(c) $10 \mathrm{~mm}$
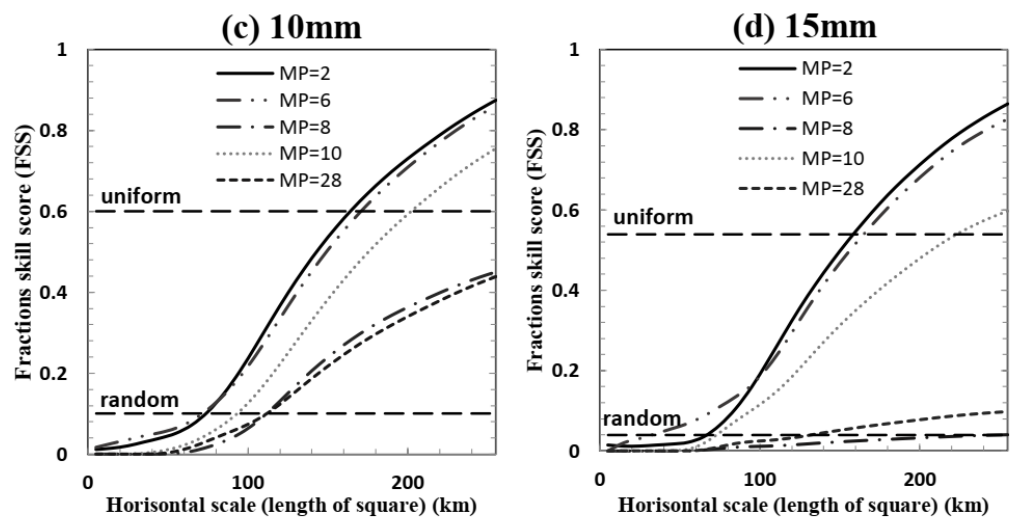

Figure 13. Chart of fractions skill score (FSS) for simulated 6h accumulated rainfall using thresholds of (a) 0.5, (b) 5.0, (c) 10.0 , and (d) $15.0 \mathrm{~mm}$.

\section{CONCLUSIONS}

In this paper, a squall line observed over Dayyer port (Iran) on 19 Mar 2017, was simulated using WRF model with $3 \mathrm{~km}$ grid spacing. The aim was to examine if the WRF model is capable to simulate the main characteristics of the squall line and whether different microphysics schemes influence to squall line simulation. For this purpose, five different microphysics schemes in the WRF model (Lin, WSM6, Morrison, Thompson and Thompson aerosol aware) were selected. The simulations showed similar results in terms of occurrence of the squall line. In general, the model using all microphysics relatively faithfully simulated the synoptic scale patterns of geopotential and sea level pressure over the southwest of Iran. Both simulated and reanalyzed fields of $500 \mathrm{hPa}$ geopotential height map show a trough over the southwest of Iran. Also, the model simulated the formation of the convective cells as close to the verifying observations. All the simulations show the passage of convective cells over the southwest of Iran, as 
observed by Doppler Weather Radar. Moreover, the spatial rainfall distribution is almost the same in all the simulations.

In general, it is found that the WRF model was capable to simulate many large scale characteristics of the squall line successfully. But examining the high resolutions reveals some significant difference between the simulations and the verifying observations. Significant differences are observed in the simulations of the number of convective cells, the vertical extent of convective cells, horizontal wind speed and direction. Also, the FSS curve for different simulations differed from each other. In brief, among the five MP schemes considered, the Lin scheme simulations were closer to observation.

These results are derived from the simulation of the single squall line. We propose to do simulations for more number of squall line observed over Iran to generalize the results obtained. This paper has found the problems associated with the simulation of characteristics of the squall line and its sensitivity to five different MP schemes.

It is interesting to attend that the Thompson scheme originally designed to improve the mid-latitude winter precipitation (Rajeevan et al. 2010). The Morrison scheme is a double moment scheme, in which the concentration of cloud ice is treated explicitly and the Thompson aerosol-aware MP scheme considers water- and ice-friendly aerosols. However, the above mentioned MP schemes failed to simulate the features associated with the squall line successfully. It is important to understand why the microphysics schemes at the WRF model had a problem in simulating the vertical extent and strength of convective cells associated with the squall line. Rajeeavan et al. (2010) stated that the reasons could be associated to the sensitivity of cumulus parameterization schemes, differences in the simulations of graupel, changes in land surface properties and initial conditions.

\section{REFERENCES}

Adlerman, E.J., Droegemeier, K. K. (2002). The sensitivity of numerically simulated cyclic mesocyclogenesis to variations in model physical and computational parameters. Monthly Weather Review. 130, 2671-2691.

Arkian, F., Karimkhani, M. (2014). Determination of the type of flood-producing thunderstorms by some convectionrelated parameters and radar images in northwestern Iran. J Climate Weather Forecasting. 2, 1-6.

Brandes, E. A., Vivekanandan, J., Wilson, J. W. (1999). A Comparison of Radar Reflectivity Estimates of Rainfall from Collocated Radars. Journal of Atmospheric and Oceanic Technology. 16, 1264-1272.

Bryan, G. H., Wyngaard, J. C., Fritsch, J. M. (2003). Resolution requirements for the simulation of deep moist convection. Monthly Weather Review. 131, 2394-2416.

Casati, B., Ross, G., Stephenson, D. B. (2004). A new intensity scale approach for the verification of spatial precipitation forecasts. Meteor. Appl. 11, 141-154.

Chen, S. H., Sun, W. Y. (2002). A one dimensional time-dependent cloud model. J. Meteorol. Soc. Japan. 80, 99-118.

Colle, B. A., Westrick, K. J., Mass, C. F. (1999). Evaluation of MM5 and Eta-10 precipitation forecasts over the Pacific Northwest during the cool season. Weather and Forecasting. 14, 137-154.

Cooper, W. A. (1986). Ice initiation in natural clouds. Precipitation Enhancement-A Scientific Challenge. Meteor. Monogr. 43, 29-32.

Chawla, I., Osuri, K. K., Mujumdar, P. P., Niyogi, D. N. (2018). Assessment of the Weather Research and Forecasting (WRF) model for simulation of extreme rainfall events in the upper Ganga Basin. Hydrology and earth system sciences. 22, 1095-1117.

Davis, C. A., Carr, F. (2000). Summary of the 1998 workshop on mesoscale model verification. Bulletin of the American Meteorological Society. 81, 809-819. 
Davis, C., Brown, B., Bullock, R. (2006). Object-based verification of precipitation forecasts. Part I: Methodology and application to mesoscale rain areas. Mon. Wea. Rev. 134, 1772-1784.

Done, J., Davis, C. A., Weisman, M. (2004). The next generation of NWP: Explicit forecasts of convection using the weather research and forecasting (WRF) model. Atmos. Sci. Lett. 5, 110-117.

Doyle, J. D. (1997). The influence of mesoscale orography on a coastal jet and rainband. Monthly Weather Review. 125, $1465-1488$.

Dudhia, J. (1989). Numerical study of convection observed during the winter monsoon experiment using a mesoscale twodimensional model. J. Atmos. Sci. 46, 3077-3107.

Ebert, E. E., McBride, J. L. (2000). Verification of precipitation in weather systems: Determination of systematic errors. J.Hydrol. 239, 179-202.

Eltahan, M., Magooda, M. (2018). Sensitivity of WRF microphysics schemes: case study of simulating a severe rainfall over Egypt. Journal of Physics: Conf. Series. 1039.

Fujita, T. T. (1978). Manual of downburst identification for Project NIMROD. Satellite and meso meteorology Res. Paper 156, Dept. of Geophysical Sciences, University of Chicago, 104.

Gilmore, M. S., Straka, S. M., Rasmussen, E. N. (2004). Precipitation and evolution sensitivity in simulated deep convective storms: comparisons between liquid-only and simple ice and liquid phase microphysics. Mon. Weather Rev. $132,1897-1916$.

Gbode, I. E., Dudhia, J., Ogunjobi, K. O., Ajayi, V. O. (2018). Sensitivity of different physics schemes in the WRF model during a West African monsoon regime. Theoretical and Applied Climatology. 136, 733-751.

Hong, S. Y., Dudhia, J., Chen, S. H. (2004). A revised approach to ice microphysical processes for the bulk parameterization of clouds and precipitation. Mon. Weather Rev. 132, 103-120.

Hong, S. Y., Lim, J. O. J. (2006). The WRF single-moment 6-class microphysics scheme (WSM6). J. Korean Meteor. Soc. $42,129-151$.

Hong, S. Y. H., Juang, M. H., Zhao, Q. (1998). Implementation of prognostic cloud scheme for a regional spectral model. Mon. Wea. Rev. 126, 2621-2639.

Jankov, I., Grasso, L., Sengupta, M., Neiman, S. J., Zupanski, D., Zupanski, M., Lindsey, D., Hillger, D. W., Birkenheuer, D. L., Brummer, R., Yuan, H. (2010). An evaluation of five ARW-WRF microphysics schemes using synthetic GOES imagery for an atmospheric river event affecting the California coast. Journal of Hydrometeorology. 12, 618-633.

Janjic, Z. (1994). The step-mountain eta coordinate model: Further developments of the convection, viscous sublayer, and turbulence closure schemes. Monthly Weather Review. 122, 927-945.

Kain, J. S., Weiss, S. J., Levit, J. J., Baldwin, M. E., Bright, D. R. (2006). Examination of convection-allowing configurations of the WRF model for the prediction of severe convective weather: The SPC/NSSL spring program 2004. Wea. Forecasting. 21, 167-181.

Kain, J. S., Weiss, S. J., Bright, D. R. (2008). Some practical considerations regarding horizontal resolution in the first generation of operational convection-allowing NWP. Wea. Forecasting. 23, 931-952.

Kain, J. S., Coauthors. (2008). Some practical considerations regarding horizontal resolution in the first generation of operational convection-allowing NWP. Wea. Forecasting. 23, 931-952.

Khain, A., Rosenfeld, D., Pokrovsky, A. (2005). Aerosol impact on the dynamics and microphysics of deep convective clouds, Q. J. Roy. Meteorol. Soc. 131, 2639-2663. 
Katzfey, J. J. (1995). Simulation of extreme new zealand precipitation events. part I: sensitivity to orography and resolution. Monthly Weather Review. 123, 737-754.

Liu, C., Moncrieff, M. W. (2007). Sensitivity of cloud-resolving simulations of warm-season convection to cloud microphysics parameterizations. Mon. Weather Rev. 135, 2854-2868.

Lean, H. W., Clark, P. A., Dixon, M., Roberts, N. M., Fitch, A., Forbes, R., Halliwell, C. (2008). Characteristics of Highresolution versions of the Met Office Unified Model for forecasting convection over the United Kingdom., Mon. Weather Rev. 136, 3408-3424.

Lin, Y. L., Farley, R., Orville, H. D. (1983). Bulk parameterization of the snow field in a cloud model, J. Climate Appl. Meteor. 22, 1065-1092.

Liu, C. H., Moncrieff, M. W., Tuttle, J. D., Carbone, R. E. (2006). Explicit and parameterized episodes of warm-season precipitation over the continental United States. Adv. Atmos. Sci. 23, 91-105.

McCumber, M., Tao, W. K., Simspon, J., Penc, R., Soong, S. T. (1991) Comparison of ice-phase microphysical parameterization schemes using numerical simulations of tropical convection. J. Appl. Meteorol. 30, 985-1004.

Morrison, H., Thompson, G., Tatarskii, V. (2009). Impact of cloud microphysics on the development of trailing stratiform precipitation in a simulated squall line: Comparison of one and two-moment schemes. Mon. Weather Rev. 137, 991-1006.

Mlawer, E. J., Taubman, S. J., Brown, P. D., Iacano, M. J., Clough, S. A. (2005). Radiative transfer for inhomogeneous atmosphere: RRTM, a validate correlated-k model for the longwave. J. Geophys. Res. 102, 16663-16682.

Morrison, H., Pinto, J. O. (2005). Mesoscale modeling of springtime Arctic mixed-phase stratiform clouds using a new two-moment bulk microphysics scheme. J. Atmos. Sci. 62, 3683-3704.

Morrison, H., Pinto, J. O. (2006). Intercomparison of bulk microphysics scheme in mesoscale simulations of springtime Arctic mixedphase stratiform clouds. Mon. Wea. Rev. 134, 1880-1900.

McQueen, J. T., Draxler, R. R., Rolph, G. D. (1995). Influence of grid size and terrain resolution on wind-field predictions from an operational mesoscale model. Journal of Applied Meteorology. 34, 2166-2181.

Martin, G. (1996). Adramatic example of the importance of detailed model terrain in producing accurate quantitative precipitation forecasts for southern California. National Weather Service. Western Region Tech. Attachment. 96-07.

Moncrieff, M. W., Liu, C. H. (2006). Representing convective organization in prediction models by a hybrid strategy. J. Atmos. Sci. 63, 3404-3420.

Meng, Z., Yan, D., Zhang, Y. (2012). General Features of Squall Lines in East China. Monthly Weather Review. 141, 1629-1547.

Meng, Z., Zhang, F., Markowski, P., Wu, D., Zhao, J. (2011). A Modeling Study on the Development of a Bowing Structure and Associated Rear Inflow within a Squall Line over South China. Journal of the Atmospheric Science. 69, 1182-1207.

Naegele, S. M. (2014). Sensitivity of a simulated squall line to the microphysical representation of Graupel. SOARS. 10, 119.

Petch, J. C., Brown, A. R., Gray, M. E. B. (2002). The impact of horizontal resolution on the simulations of convective development over land. Quart. Roy Meteor Soc. 128, 2031-2044.

Reisner, J., Rasmussen, R. J., Bruintjes, R. T. (1998). Explicit forecasting of super cooled liquid water in winter storms using the MM5 Mesoscale model, Q. J. Roy. Meteorol. Soc. 124B, 1971-1107.

Rutledge, S. A., Hobbs, P. V. (1984). The mesoscale and microscale structure and organization of clouds and precipitation in midlatitude cyclones XII: A diagnostic modeling study of precipitation development in narrow clod-frontal rainbands. $J$. Atmos. Sci. 41, 2949-2972. 
Rajeevan, M., Kesarkar, A., Thampi, S. B., Rao, T. N., Radhakrishna, B., Rajasekhar, M. (2010). Sensitivity of WRF cloud microphysics to simulations of a severe thunderstorm event over Southeast India. J. Annales Geophysicae. 28, 603-619.

Roberts, N. M., Lean, H. W. (2007). Scale-Selective Verification of Rainfall Accumulations from High-Resolution Forecasts of Convective Events. Monthly Weather Review. 136, 78-97.

Song, H. J., Sohn, B. J. (2018). An evaluation of WRF microphysical schemes for simulating the warm type heavy rain over the Korean peninsula. Asia-Pac. J. Atmos. Sci. 54, 225-236.

Skamarock, W. C., Klemp, J. B., Dudhia, J., Gill, D. O., Barker, D. M., Wang, W., Powers, J. G. (2005). A description of the Advanced Research WRF version 2. NCAR Tech. Note NCAR/TN-468_STR, 88.

Schwartz, C. S., Coauthors. (2009). Next-day convection-allowing WRF model guidance: A second look at 2-km versus 4km grid spacing. Mon. Wea. Rev. 137, 3351-3372.

Shrestha, R. K., Connolly, P. J., Gallagher, M. W. (2017). Sensitivity of WRF cloud microphysics of simulations of a convective storm over the Nepal Himalayas. The open atmospheric science journal. 13, 29-43.

Stergiou, I., Tagaris, E., Eleni, R., Sotiropoulou, P. (2017). Sensitivity Assessment of WRF Parameterizations over Europe. MDPI. 119, 1-16.

Trier, S. B., Davis, C. A., Ahijevych, D. A., Weisman, M. L., Bryan, G. H. (2006). Mechanisms supporting long-lived episodes of propagating nocturnal convection within a 7-day WRF model simulation. J. Atmos. Sci. 63, $2437-2461$.

Thompson, G., Rasmussen, R. M., Manning, K. (2004). Explicit forecasts of winter precipitation using an improve bulk microphysics scheme. Part-I: Description and sensitivity analysis. Mon. Weather Rev. 132, 519-542.

Tao, W. K., Simpson, J., McCumber, M. (1989). An ice-water saturation adjustment. Mon. Wea. Rev. 117, $231-235$.

Troen, I., Mahrt, L. (1986). A simple model of the atmospheric boundary layer: Sensitivity to surface evaporation. Boundry-Layer Meteor. 47, 129-148.

Thompson, G. G., Eidhammer, T. (2014). A study of aerosol impacts on clouds and precipitation development in a large winter cyclone. Journal of the atmospheric sciences, 71 (10), 3636-3658.

Tao, W. K., Shi J. J., Chen, S. S., Lang, S., Lin, P. L., Hong, S. Y., Lidard, C. P., Hou, A. (2011). the impact of microphysical schemes on hurricane intensity and track. Asia-Pac. J. Atmos. Sci. 47, 1-16.

Tan, E. (2016). Microphysics parameterization sensitivity of the WRF Model version 3.1.7 to extreme precipitation: evaluation of the 1997 New Year's flood of California. Geoscienfitic model development. 94, 1-29.

Weisman, M. L., Davis, c., Wang, W., Manning, K. W., Klemp, J. B. (2008). Experiences with 0-36-h explicit convective forecasts with the WRF-ARW model. Wea. Forecasting. 23, 407-437.

Walko, R. L., Cotton, W. R., Meyers, M. P., Harrington, J. Y. (1995). New RAMS cloud microphysics parameterization. Part I: The single-moment scheme. Atmos. Res. 38, 29-62.

Wong, K.Y., Yip, C.L. (2006). Comparison of Squall Line Positioning Methods Using Radar Data. Lecture Notes in Computer Science. 4253.

Wilson, J. M., Crook, N. A., Mueller, C. K., Sun, J., Dixon, M. (1998). Nowcasting thunderstorms: A status report, B. Am. Meteorol. Soc. 79, 2079-2099.

Xue, M., Martin, W. J. (2006). A high-resolution modeling study of the 24 may 2002 dryline case during IHOP. part I: Numerical simulation and general evolution of the dryline and convection. Monthly Weather Review. 134(1), 149-171. 